\title{
Levels of Apigenin and Immunostimulatory Activity of Leaf Extracts of Bangunbangun (Plectranthus Amboinicus Lour)
}

\author{
Melva Silitonga $^{1}$, Syafruddin Ilyas ${ }^{2}$, Salomo Hutahaean ${ }^{2} \&$ Herbert Sipahutar $^{1}$ \\ ${ }^{1}$ Biology Education Department, Faculty of Mathematic and Science, State University of Medan, Medan, \\ Indonesia \\ ${ }^{2}$ Biology Department, Faculty of Mathematic and Science, University of North Sumatra, Medan, Indonesia \\ Correspondence: Melva Silitonga, Biology Education Department, Faculty of Mathematic and Science, State \\ University of Medan, Medan, Indonesia. E-mail: Melvasil-2014@gmail.com
}

Received: October 2, 2014 Accepted: October 18, 2014 Online Published: October 22, 2014

doi:10.5539/ijb.v7n1p46 URL: http://dx.doi.org/10.5539/ijb.v7n1p46

\begin{abstract}
Bangunbangun (Plectranthus amboinicus Lour) consumed by the mother, who just gave birth in North Sumatra, Indonesia in particular the Batak tribe, to increase the production of breast milk. This plant is known to have a high content of nutrients, especially iron and carotene. Also known to have many benefits, among others, as an antipyretic, analgesic, wound medicine, cough medicine, and thrush, antioxidant, antitumor, anticancer, and hypotensive. The study was conducted to determine levels of apigenin of Bangunbangun's leaves and evaluate its immunostimulatory activity in rats (Rattus norvegicus). Analysis of apigenin using High Performance Liquid Chramtography method (HPLC). Evaluation of immunostimulatory activity carried out by measuring the levels of imonoglobulin G (IgG), imonoglobulin M (IgM), Lysozyme and Monocytes. Analysis of IgG and IgM are using Elisa method (Sigma). Serum lysozyme activity was measured by the spectrophotometric method. Monocytes were analyzed by using ABX Micros 60. Organ histology preparations made by hematoxylin-eosin staining. Data were analyzed by ANOVA and showed that by giving the Ethanol Extract of Propolis (EEP) of $500 \mathrm{mg} / \mathrm{kg}$ bw in rats, with a significant increase of IgM and lysozyme activity with very significant. EEP give a very significant effect on levels of IgG. Monocytes were higher in mice given EEP, but did not differ significantly compared with mice not given EEP. Lymphoid organ weights are all under normal circumstances. Giving EEP $500 \mathrm{mg} / \mathrm{kg}$ bw mice, significantly increased the weight of the liver and spleen, but does not affect kidney weight.
\end{abstract}

Keyword: Plectranthus amboinicus Lour, IgG, IgM, Lysozyme, monocytes, spleen, liver, thymus, kidney

\section{Introduction}

Traditional medicine plays an important role in maintaining the health of humans and animals. By consuming medicinal plants, can boost the immune system and increase antioxidant activity in humans. The high level of use as a medicinal plant due to easily available, cheap, and relatively no side effects (Lie et al., 2010; Gabhe, Tathe, \& Khan, 2006). Natural immunostimulants are biocompatible, biodegradatif, low prices and friendly environment. Therefore, its use has been widely used as a cure for several diseases, cosmetics, immunostimulant and a variety of other purposes (Ortuno et al., 2002). Plants have been used as medicine in India, Nigeria, China, Indonesia and some other countries (Uma et al., 2011). Immunomodulator is a substance that affects the immune system and how to restore and repair the impaired immune system and suppress excessive immune function (Małaczewska et al., 2010; Bellanti \& Kadlec, 1993). Based on how it works can be divided into imunostimulant Immunomodulatory and imunosupresant.

Bangunbangun is a type of plant that is commonly consumed by mothers who gave birth in North Sumatra, in particular the Batak tribe. Bangunbangun's leaves is believed to increase the production of breast milk. These leaves have a high content of nutrients, especially iron and carotene. Consumption of leaf shapes significantly affect the elevated levels of some minerals such as iron, potassium, zinc and magnesium in milk and infant weight resulting in increased markedly. And is known to have many benefits, among others, as an antipyretic, analgesic, wound medicine, cough medicine, and thrush, antioxidant, antitumor, anticancer, and hypotensive ((Damanik et al., 2001; Duke, 2000). Usually drugs that have multiple properties have receptors on the target organ systems that perform the function of immune limforetikular. Apigenin is a flavonoid which is the active substance contained in the parsley and known to have antioxidant properties and effectively inhibiting the prooxidative activity of 
cadmium, the effects of anti-lung cancer Pru and inhibiting the growth of human colon carcinoma cells (Tong et al., 2007; Liu et al., 2005; Wang et al., 2000).

Bangunbangun's leaves contain various flavonoids apigenin, quercetin, luteolin, salvigenin, genkwanin and fat to fly, which is a phenolic compound that is widespread in plants and have been reported to have multiple biological effects, including antioxidant, eliminating free radicals have the ability of anti-inflammatory and anti-cancer activity . (Prasenjit, Hullanti, \& Khumar, 2011; Preeja et al., 2011).

Immunostimulatory activity of a drug or medicinal plants observed by measuring several parameters, namely, immunoglobulin $G(\operatorname{Ig} G)$ and immunoglobulin $M(\operatorname{IgM})$ and some hematological parameters. Hematocrit, total leukocytes, total protein, total immunoglobulin and leukocrit are parameters immunostimulatory activity of the immune response and can be measured through serological and hematological tests (Dorucu et al., 2009; Khumar, Gupta, Sharma, \& Khumar, 2011). Defense mechanisms of the simplest animals is phagocytosis. Although various cells in the body can perform phagocytosis, but the main cells involved in nonspecific defense is the mononuclear cells (monocytes and macrophages) and polymorphonuclear granulocytes or (Munasir, 2001).

Lysozyme is one of the parameters measured as the impact of the use of immunostimulant. It is found in many vertebrates including fish, and is an important factor to prevent the invasion of microorganisms (Ogier, Quentell, Fournierl, \& Guovello, 1996). This issue became the basis for examining the role of bangunbangun's extract as an anti-bacterial that can increase lysozyme activity in the body.

\section{Method and Material}

\subsection{Procurement and Extraction of Bangunbangun's Leaves}

The fresh Bangunbangun's leaves was taken as much as $8 \mathrm{~kg}$, and washed with water and then it dried naturally for 24 hours. To get the brittle bangunbangun's leaves, drying is done with an oven with a temperature of $40^{\circ} \mathrm{C}$. As much as $500 \mathrm{~g}$ of dried leaves were pulverized in a blender until powder form, which is placed in two container, ie each 250 grams of $95 \%$ ethanol and added to the already distilled some $2000 \mathrm{ml} /$ container. Wheat leaves soaked for 5 days, and then stirred once a day. Immersion leaf powder was filtered using filter paper and add up to 3 liters of ethanol, and left for 2 days and filtered again. Extract obtained was concentrated by using a rotary evaporator using a water bath and then it dried to obtain the dried ethanol extract.

Bangunbangun ethanol extract dose to rats at $500 \mathrm{mg} / \mathrm{kg}$ (Jose, Ibrahim, \& Janardhanan, 2005; Patel et al., 2011). Ethanol extract of the bangunbangun's leaves dissolved in 1\% CMC (Jose, Ibrahim, \& Janardhanan, 2005). Bangunbangun ethanol extract solution was made $10 \%$ solution. Bangunbangun extract given orally every day by means of force-feeding, for 30 days.

\subsection{Chemicals}

In analyzing serum immunoglobulin was used Elisa Kit Rat IgG and IgM (Cat. No. E111-100), Rat IgM Elisa Kit (Sigma), Rat IgG Elisa Kit (Sigma), ELISA Coating Buffer (Cat. No. E107), ELISA wash Buffer Solution (Cat. No. E106), ELISA blocking buffer (Cat. No. E104) dan96- well plate (Cat. No. E105). Lysozyme kit is used to measure the levels of lysozyme in the serum. HPLC Apegenin Standards was used to determine levels of apigenin in bangunbangun's leaves.

\subsection{Animal Test}

Tests was conducted on a many of 24 white rats in aged 3 months with an average weight of 150-200 grams and adapted to laboratory conditions for 14 days. The health condition of the mice was controlled every day and there are no signs of illness such as no appetite, weight loss and decreased motor activity. Future provision of treatment carried out for 30 days. Rats were given food in the form pellets and drinking water. The temperature in the room ranged between $(22 \pm 2){ }^{\circ} \mathrm{C}$ with 12 hours dark cycle and 12 hours of light.

\subsection{Sheep Red Blood Cells (SRBC)}

SRBC antigen used is according to research conducted by Khoul and Khosa (2013). SRBC were made in the laboratory of the Veterinary Regional I Medan, North Sumatra, Indonesia. Making SRBC was done with fresh sheep blood that had been given an anticoagulant, centrifuged at $3000 \mathrm{rpm}$ to separate plasma from red blood cells. The top layer is a pasteur pipette plasma discarded, and the bottom layer, which is a red blood cell sediment was added a solution of PBS pH 7.2 three times of the volume of SRBC remaining. Tube is then turned upside down slowly until SRBC suspended homogeneously, and then centrifuged again. This procedure is repeated until the top layer is really clear and colorless. Clear upper layer was discarded and the bottom layer is $100 \%$ SRBC suspension To get the suspension SRBC 50\% is done by adding $0.5 \mathrm{ml}$ of $100 \%$ SDMD suspension with $0.5 \mathrm{ml}$ of PBS. And then to get the suspension SRBC 1\%, ie by adding $1 \mathrm{ml}$ of $50 \%$ suspension in PBS SRBC $50 \mathrm{ml}$. 


\subsection{Apigenin Measurement and Evaluation of Immunostimulatory Activity}

Apigenin was measured by HPLC. Evaluation of immunostimulatory activity performed by Completely Randomized Design (CRD), with four treatments were each given six replicates. 24 white rats. There are four groups and each group consisted of 6 rats. In detail, these groupings are as in Table 1.

Table 1. Grouping of rats

\begin{tabular}{ccc}
\hline \multirow{2}{*}{ Group } & \multicolumn{2}{c}{ Treatment } \\
\cline { 2 - 3 } & \multicolumn{1}{c}{ Control } & \multicolumn{1}{c}{ Experiment } \\
\hline 1 & CMC 1\% orally every day & \multicolumn{1}{c}{-} \\
3 & - & EEP $500 \mathrm{mg} / \mathrm{kg} \mathrm{bw}$, no give SRBC \\
4 & - & EEP $500 \mathrm{mg} / \mathrm{kg}$ bw, give $0,1 \mathrm{ml} \mathrm{SRBC}$ \\
\hline
\end{tabular}

EEP was given orally using a gastric tube every day for 30 days, and SRBC was given intraperitoneally on day 8 and day 15 of treatments. Weight recorded at the end of each week to determine the effect of EEP on body weight. Blood samples were obtained from all test animals at day 31 by decapitation neck. Serum was separated for measurement of $\mathrm{IgG}$ and $\mathrm{IgM}$.

Serum lysozyme activity was measured following the factory procedure (Sigma Cat Number L7651). Measurement of lysozyme based lysis suspension bacteria Micrococcus process lysodeiktycus according to the method that developed by Ellis (1998). Details are described as follows. $0.15 \mathrm{mg} / \mathrm{ml}$ Micrococcus lysodeiktycus (Sigma) dissolved in $66 \mathrm{mM}$ PBS (pH 6.2). $50 \mu \mathrm{L}$ of serum was added to $1 \mathrm{ml}$ of bacterial suspension. Decrease in absorbance was recorded at 0.5 and $4.5 \mathrm{~min}$ for $3 \mathrm{~min}$ on a spectrophotometer with a wavelength of $450 \mathrm{nM}$. One unit of lysozyme activity is defined as a decrease in absorbance of $0.001 \mathrm{~L} / \mathrm{min}$.

\subsection{Measurement of Monocytes}

On day 31, the treatment were collected for analysis of blood monocytes. Blood was obtained by decapitation neck, then collected in a tube that has been coated with EDTA. The analysis is done using a monocyte ABX Micros 60 .

\subsection{Measurement of Organ Weight}

The organs were measured liver, spleen, thymus and kidney. To get the weight of these organs, surgery on rats have blood drawn by means of decapitation neck. To the four above-mentioned organs removed and placed on strain paper, and then weighed. All ortikus was stored in a solution of 10 percent formalin for further-processed for histopathological observations.

\section{Results}

\subsection{Evaluation of Immunostimulatory Activity}

\subsubsection{IgG dan IgM Avtivity}

Giving EEP $500 \mathrm{mg} / \mathrm{kg}$ bw had no effect on the activity of rat's IgG (Table 2). IgG activity was highest in the control treatment, followed by treatment with $500 \mathrm{mg}$ of EEP. Activity is the lowest IgG in mice that were given only SRBC.

Giving EEP $500 \mathrm{mg} / \mathrm{kg}$ bw rats that given antigen SRBC showed significant changes in the levels of IgM, compared with control mice. IgM of rats that given EEP $500 \mathrm{mg} / \mathrm{kg}$ bw and were not given SRBC, higher than IgM of control rat, and IgM higher than mice given only SRBC, but this difference was not significant. This data can be seen in Table 2. This shows the effect of ethanol extract of leaf shapes to increase levels of immunoglobulin $\mathrm{M}$ in white rats. Groups of rats were given only SRBC treatment, had higher levels of immunoglobulin M, higher than the control group who were given distilled water alone. This may be influenced antigen into the body where the proliferation of rat antibodies against these antigens. 
Table 2. Effect of EEP against IgG, IgM and Monocyte Lysozyme of mice

\begin{tabular}{|c|c|c|c|c|c|}
\hline \multirow[b]{2}{*}{ No } & \multirow[b]{2}{*}{ Treatment } & \multicolumn{4}{|c|}{ Parameter } \\
\hline & & $\begin{array}{c}\mathrm{IgM} \\
\left(\mathrm{ng} / \mathrm{ml} \times 10^{5}\right)\end{array}$ & 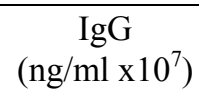 & $\begin{array}{l}\text { Lysozyme } \\
\mathrm{U} / \mathrm{ml} \mathrm{x} 10\end{array}$ & $\begin{array}{c}\text { Monocytes } \\
(\%)\end{array}$ \\
\hline 1 & $\mathrm{CMC}$ & $3.19 \pm 1.26$ & $3.18 \pm 0.66$ & $0.191 \pm 0.0110$ & $12.8 \pm 3.02$ \\
\hline 2 & $\begin{array}{c}500 \mathrm{mg} \mathrm{EEP} / \mathrm{kg} \\
\text { bw }\end{array}$ & $4.33 \pm 2.26$ & $5.73 \pm 1.12 * *$ & $0.622 \pm 0.0051^{* *}$ & $15.5 \pm 3.56^{*}$ \\
\hline 3 & $\begin{array}{c}500 \mathrm{mg} \text { EEP } / \mathrm{kg} \\
\mathrm{bw}+\mathrm{SRBC}\end{array}$ & $8.01 \pm 4.52$ & $3.68 \pm 0.52$ & $1.49 \pm 0.056^{* *}$ & $15.15 \pm 2.45^{*}$ \\
\hline 4 & $0.1 \mathrm{ml} \mathrm{SRBC}$ & $3.93 \pm 1.86$ & $3.79 \pm 0.85$ & $0.442 \pm 0.0026^{*}$ & $15.12 \pm 4.21^{*}$ \\
\hline
\end{tabular}

\subsubsection{Monocyte}

Highest levels of monocytes were found in mice given EEP $500 \mathrm{mg} / \mathrm{kg}$ bw, followed by monocyte levels in mice treated EEP $500 \mathrm{mg} / \mathrm{kg}$ bw + SRBC, and rats were given only SRBC (Table 2). Monocyte levels were lowest in the control mice, but was not statistically significantly different.

\subsubsection{Lysoizime Activity}

Lysozyme activity data can be seen in Table 1 Giving EEP $500 \mathrm{mg} / \mathrm{kg}$ bw to rats increases the activity of lysozyme is very significant. The highest lysozyme activity found in rats treated EEP $500 \mathrm{mg} / \mathrm{kg} \mathrm{bw}+$ SRBC, followed by lysozyme treatment mice EEP $500 \mathrm{mg} / \mathrm{kg}$ bw. Lysozyme in mice both treatments was higher and significantly different compared with controls. Mice that were given only SRBC, the activity of its lysozyme was higher and significantly different compared with controls.

\subsection{Effect of EEP on Organ Weights}

The results of organ weight measurement was shown in Table 3, indicate that EEP administration of $500 \mathrm{mg} / \mathrm{kg}$ bw, significant effect on liver weight, and spleen. EEP effect of $500 \mathrm{mg} / \mathrm{kg} \mathrm{bw}+\mathrm{SRBC}$ to the weight of the spleen, and kidney and thymus weight in control rats significantly different compared to all treatments.

Table 3. Effect of EEP against organ weights of mice

\begin{tabular}{cccccc}
\hline \multirow{2}{*}{ No } & \multirow{2}{*}{ Treatment } & \multicolumn{4}{c}{ Organ Weight $(\mathrm{g})$} \\
\cline { 3 - 6 } & & Liver & Spleen & Kidney & Thymus \\
\hline 1 & $\mathrm{CMC}$ & $4.68 \pm 1.14$ & $0.28 \pm 0.05$ & $1.62 \pm 0.09$ & $0.80 \pm 0.08^{* *}$ \\
2 & $500 \mathrm{mg} \mathrm{EEP} / \mathrm{kg} \mathrm{bw}$ & $6.89 \pm 1.12^{*}$ & $0.51 \pm 0.04^{*}$ & $1.35 \pm 0.21$ & $0.59 \pm 0.05$ \\
3 & $500 \mathrm{mg} \mathrm{EEP} / \mathrm{kg} \mathrm{bw}+\mathrm{SRBC}$ & $5.73 \pm 0.60$ & $0.68 \pm 0.19^{*}$ & $1.47 \pm 0.17$ & $0.49 \pm 0.07$ \\
4 & $1 \mathrm{ml} \mathrm{SRBC}$ & $6.38 \pm 1.50^{*}$ & $0.46 \pm 0.03$ & $1.25 \pm 0.18$ & $0.55 \pm 0.06$ \\
\hline
\end{tabular}

\subsection{Mesurement of Apigenin Liver, Spleen, Kidney}

Apigenin has been recognized in general medicine or in traditional medicine for its pharmacological activity. An important group of flavonoids are anthocyanins, flavonols, flavones, catechins, and flavanones. Apigenin is a group of flavonoids (Hertog et al., 1993). Apigenin was measured by HPLC technique. The measurement results showed that there were as many as apigenin $0.0236 \mathrm{ng} / \mu 1$ samples at bangunbangun's leaves. Figure $1 \mathrm{a}$ and $1 \mathrm{~b}$ shows the retention times and measurements of leaf bangunbangun apigenin. 


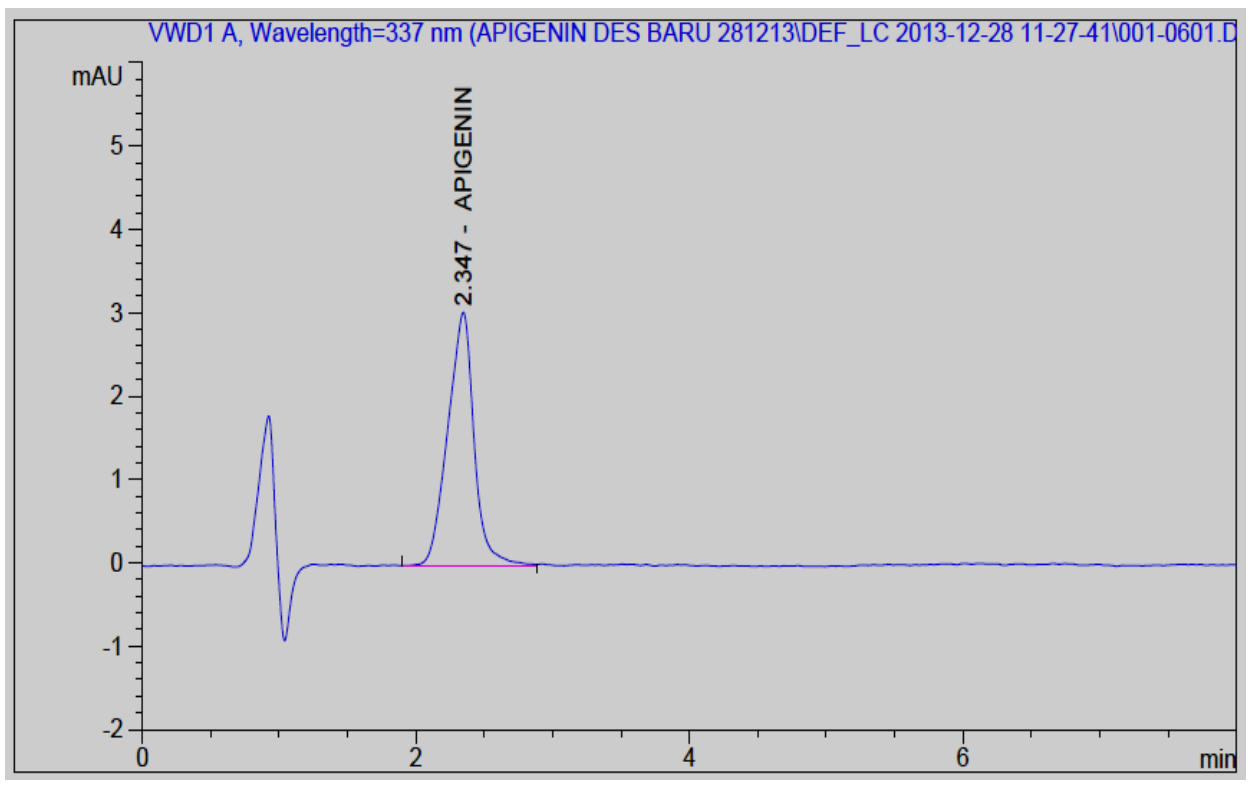

Figure 1a. Apigenin retention times

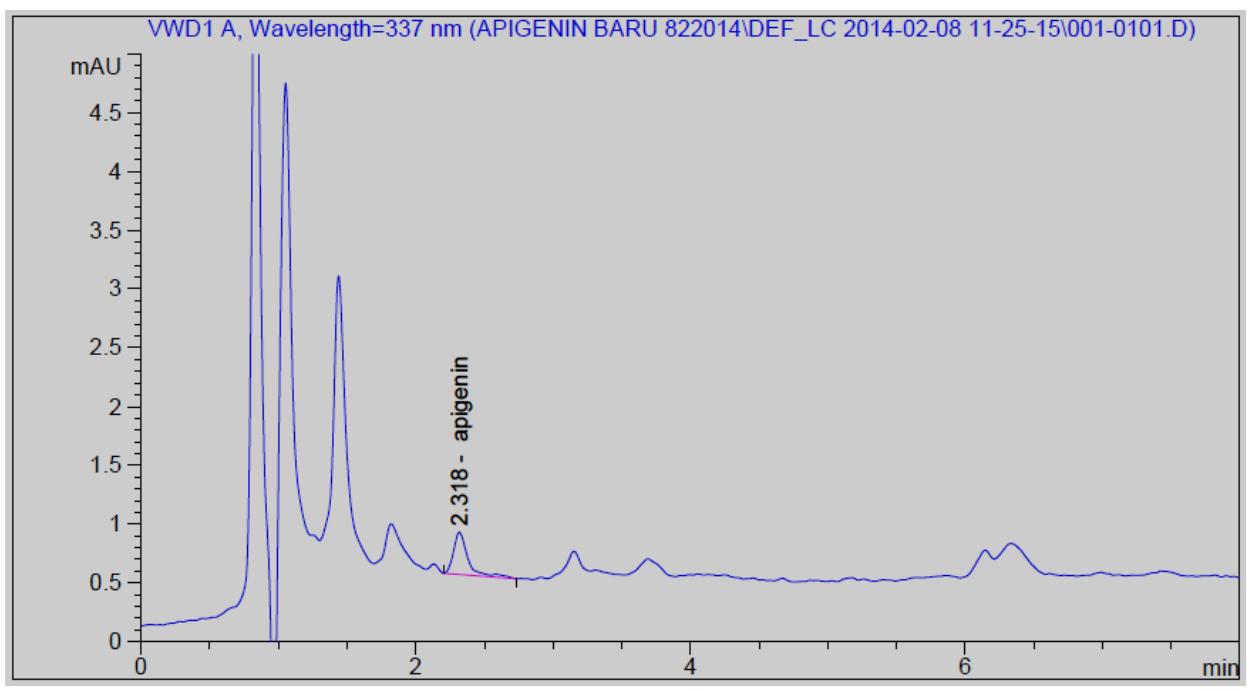

Figure 1. b. Apigenin content

\section{Discussion}

$\operatorname{IgD}$ and IgM is the main immunoglobulin found on the surface of B lymphocytes. There are two classes of immunoglobulin in the form and shape of a layered circular membrane that serve as receptors for specific antigens. The result of this interaction is further proliferation and differentiation of B lymphocytes, which produce antibody-secreting plasma cells. IgM circular also effectively activate the complement system, which is a group of plasma proteins made in the liver (Junqueira and Carneiro, 2003). Immunoglobulin M is the first immunoglobulin class formed on antigen stimulation, but IgM responses are generally short lasting only a few days and then decreased. Due to the high valency, IgM antibodies are very efficient as the cause clumping or cell destroyer. Because IgM are mostly found in the blood and rapidly increased in response to infection.

Giving EEP $500 \mathrm{mg} / \mathrm{kg}$ bw for 30 days and the mice were given antigen SRBC on day 8 and 15 significantly increased the levels of IgM, compared with controls. Increased IgM occurs in mice exposed to antigen SRBC. EEP IgM mice given $500 \mathrm{mg} / \mathrm{kg}$ bw higher than controls and were only given SRBC, but did not differ significantly in this regard EEP increase IgM production upon exposure to antigen. Giving EEP $500 \mathrm{mg} / \mathrm{kg}$ bw mice for 30 days with a very real increase of IgG compared with controls. This increase occurred without exposure to antigen SRBC. IgG levels was lower than IgM. This is consistent with the theory that exposure to foreign antigen will produce 
biphasik response. The first stage is associated with the production of IgM, followed by IgG production. The second stage is characterized by a decrease followed by an increase in $\operatorname{IgG~IgM~just~as~shown~in~Figure~} 2$ Antigen will select and expand clones of effector B cells that will develop into plasma cells and produce antibodies.

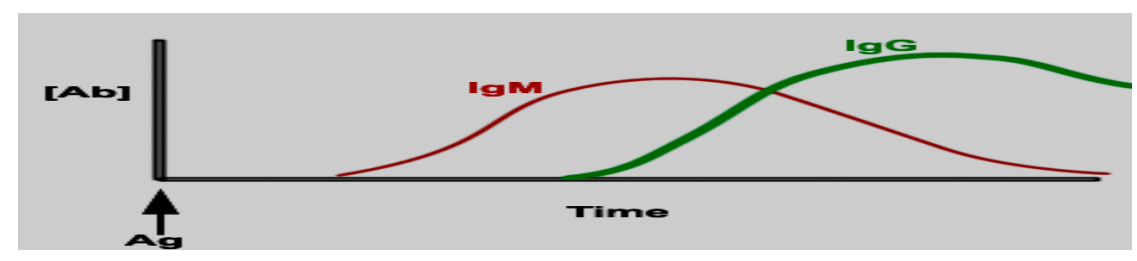

Figure 2 Production of $\operatorname{IgG}$ and IgM after antigen exposure

Lysozyme is an enzyme that has the power antiseptics, which can kill foreign organisms. This enzyme is present in the blood cells of granulocytes and monocytes, and also contained in saliva, sweat, and tears of the mammary gland (Millodot, 2009). Lysozyme protects several places in the body which is a potential place for food for bacterial growth. Lysozyme provides protection in the blood, with methods that are stronger than the one used by the immune system. Immunostimulatory bind specific receptors on the surface membrane of phagocytes. Lymphocytes were mengaktavasi these cells, produce several enzymes including lysozyme to destroy pathogens (Fazlolahzadeh et al., 2011). EEP is as an antibacterial as reported by Shiney, Ganesh, and Kumar (2012). Thus the antibacterial properties of the EEP increases with increasing serum Lysozyme. Increased activity of lysozyme in the serum of mice along with increased levels of monocytes. This is in accordance with that stated by Millodot (2009), that was formed by the lysozyme enzyme neutrophill or monocytes.

Cells monosit'merupakan one of the components of the white blood cells (leukocytes), which function to phagocytosis. Monocites role in phagocytic cells when the host first meeting with a foreign object (Bellanti, 1993). These cells will be stimulated sums in the event of infection or chronic inflammation, have a short shelf-life in the blood circulation then into the network and turn into macrophages (Guyton, 1995). Monocytes are motile and move with amuboid movement to areas experiencing chronic infection for the phagocytic response (Ganong, 1999). Monocytes and macrophages are the second most frequent type of leukocytes. Macrophages play an important role in the immune response caused by fagositiknya properties, its ability to secrete cytokines and kemokinin, and his ability as a pointer cell antigens.

The measurement results showed that there apigenin apigenin as $0.0236 \mathrm{ng} / \mathrm{ml}$ sample. This is in accordance with the opinion of Prasenjit, Hullanti, and Khumar (2011) and Preeja et al. (2011) which says that bangunbangun leaves contain various flavonoids apigenin, quercetin, luteolin, salvigenin, genkwanin and fat to fly. However the measurement of quercetin, luteolin, salvigenin, genkwanin and fat still needs to be done.

The organs involved in the body's immune system are the spleen, liver, kidneys, thymus and lung. There are two main functions of the spleen is to produce a specific immune response and destroy the red blood cells are abnormal. Increased functional activity of the spleen, which is accompanied by hyperplasia limphoid cells or macrophages are usually caused by the stimulation of antigen or the presence of foreign bodies in the blood. Just as shown in Table 3, that the spleen of mice given EEP and SRBC heavier in comparison with other treatments. In this case give SRBC as antigen stimulation of spleen enlargement. Spleen mice given EEP has a greater weight than that given only SRBC. It also can stimulate the EEP shows an enlarged spleen. Magnification is caused by activities in producing immunoglobulins. The absence of stimulants in the control group of mice spleen menyebapkan can not optimally capture antigen and its size was smaller than the other treatments. Despite the significant changes in spleen weight with EEP administration, but all the organs of the spleen is still in the normal range is $0.58 \pm 0.10$ $0.72 \pm 0.14 \mathrm{~g}$. Spleen size bigger makes it easier spleen in preparation to capture antigen. In addition, a large spleen size also because the number of lymphocytes that formed in the spleen, this EEP showed good immunostimulatory effect on spleen is in line with the statement Piao, Liu, and Xie. (2013).

Giving EEP $500 \mathrm{mg} / \mathrm{kg}$ bw significantly affect liver weight. The highest liver weight was $6.89 \pm 1.12$. This size is still within the normal range, because according to Piao, Liu, and Xie (2013) for rats aged 13 months with an average weight of $6.70 \pm 0.96 \mathrm{~g}$ liver. The liver is an organ with predominant innate immunity, plays an important role not only in the body's defense against invading microorganisms and tumor transformation but also in liver injury and recovery (Gao, Jeong, \& Zhigang, 2008). 
The thymus is the first lymphoid organ to form and grow slowly after birth in response to antigen stimulation posnatal and to ask for a large number of mature $T$ cells. Genetic factors also affect, age, the rate and degree of immunologic function needs. In rats and mice, along with the maximum size is reached sexual maturity and then slowly experiencing involution (Pearse, 2006). In this study, the thymus weight decreased by administration of EEP $500 \mathrm{mg} / \mathrm{kg}$ bw. In the control rat thymus weight was higher than all other treatments. Weight of the thymus in mice is $12: 50 \pm 0.004$ to $0.62 \pm 0.001$.

In newborn animals thymus is relatively large and mature sex before gradually shrinking (having involution) and replaced by fatty tissue (Hartono, 1989). But the rest of the thymus were found in the thoracic space remain on the animal until some old. Besides involution was associated with age, thymic atrophy was also faster in response to stress, so that the animals that died after a long illness that has a very small thymus (Tizard, 2004). The results of measurements performed thymus weight all showed still within the normal range, but the thymus weight control treatment was significantly different compared to the other treatments. Based on this can be called that thymus organ weight have anything to do with giving bangunbangun that spur these organs in improving the body's immune system.

Kidney is most often targeted by the immune response against pathogens kidney autoantigen or local manifestations of systemic autoimmunity (Kurts et al., 2013). Kidney failure affects immunity in general, cause intestinal barrier dysfunction, systemic inflammation and immunodeficiency that contribute to morbidity and mortality of patients with kidney disease. Giving EEP $500 \mathrm{mg} / \mathrm{kg}$ bw did not affect kidney weight. This is shown in Table 3 that all the kidney in the normal range.

\section{Acknowledgements}

The author would like to thank Mr. Hamonangan Tambunan, Lecturer of the Faculty of Engineering, State University of Medan for helping the author.

\section{References}

Alvin Jose, M., \& Janardhanan, S. (2005). Modulatory effect of Plectranthus amboinicus Lour. on ethylene glycol-induced nephrolithiasis in rats. Indian journal of pharmacology, 37(1), 43. http://dx.doi.org/10.4103/ 0253-7613.13857

Bellanti, J. A. (1993). Immunologi III. Terjemahan dari Immunology III oleh A. Samik Wahab. Yogyakarta: Gadjah Mada University Press.

Damanik, R., Damanik, N., Daulay, Z., Saragih, S., Premier, R., Wattanapenpaiboon, N., ... Wahlqvist, L. (2001). Consumption of Bangun-Bangun Leaves (Coleus amboinicus Lour) to Increase Breast Milk Production Among Bataknesse Women in North Sumatra Island, Indonesia. Retrieved January 2011 from www.healthyeatingclub.com/APJCNutSOO1/Damanik67.pdf

Dorucu, M., Colak, O. S., Ispir, U., Altinterin, B., \& Celayir, Y. (2009). The Effect of Black Cumin Nigella sativa on the immune response of Rainbow Trout, Oncorhynchus mykiss. Mediterranian Aquaculture Journal, 2(1), 27-33. http://dx.doi.org/10.1016/j.aquaculture.2013.01.008

Duke. (2000). Dr. Duke's Constituens and Ethnobotanical Databases. Phytochemical database, USDA ARS-NGRL. http://dx.doi.org/10.5860/choice.38-3317

Ellis, A. (1988). Fish faccination (pp. 1-16). San Diego: Academic Press.

Gabhe, S. Y. Tatke, P. A., \& Khan, T. A. (2008). Evaluation of the immunomodullatory activity of the methanol extract of Ficus benghalensis roots in rats. Indian J. Pharmacol, 38(4), 271-275. http://dx.doi.org/10.4103/0253-7613.27024

Ganong, W. F. (1999). Review of Medical Physiology. Translater: Adji Dharma. Fisiologi Kedokteran. Edisi 9. Jakarta: Penerbit Buku Kedokteran.

Gao, B., Jeong, W., \& Zhigang, T. (2008). Liver: An Organ with Predominant Innate Immunity. Hepatology, 47, 729-736. http://dx.doi.org/10.1002/hep.22034

Guyton, A. C. (1995). Buku Ajar Fisiologi Kedokteran. Ed ke-7. Jakarta: Penerbit Buku Kedokteran EGC.

Hartono. (1989). Bahan Pengajaran Histologi Veteriner. Departemen Pendidikan dan Kebudayaan Direktorat Jendral Pendidikan Tinggi Pusat Antar Universitas Ilmu Hayat, Institut Pertanian Bogor.

Junqueira, L., \& Carnero, J. (2007). Histologi Dasar. Jakarta: Buku kedokteran EGC.

Khoul, S., \& Khosa, R. L. (2013). Immunomodullatory activity of phytoconstituent of Melissa officinalis. Der Pharmacia Lettre, 5(1), 141 -145. 
Khumar, S., Gupta, P., Sharma, S., \& Khumar, D. (2011). A Review on Immunostimulatory plant. Journal of Chinese Integrative Medicine, 9(2), 117 -128. http://dx.doi.org/10.3736/jcim20110201

Kurts, Ch., Panzer, U., Anders, H., \& Andrew, R. J. (2013). The immune system and kidney disease: Basic concepts and clinical implications. Nature ReviewsImmunology, 13, 738-753. http://dx.doi.org/10.1038/ nri3523

Kurts, Ch., Panzer, U., Hans-Joachim, A., \& Andrew, J. R. (2013). The immune system and kidney disease: basic concepts and clinical implications. Nature Reviews Immunology, 13, 738-753. http://dx.doi.org/10.1038/nri3523

Lee, T. T., Huang, C. C., Shieh, X. H., Chen, C. L., Chen, L. J., \& Yu, B. I. (2010). Flavonoid, phenol and polysaccharide contents of Echinacea purpurea L. and its immunostimulant capacity in vitro. Int $J$ Environ Sci Dev, 1, 5-9. http://dx.doi.org/10.7763/ijesd.2010.v1.2

Liu, L. Z., Fang, J., Zhou, Q., Hu, X., Shi, X., \& Jiang, B. H. (2005). Apigenin inhibits expression of vascular endothelial growth factor and angiogenesis in human lung cancer cells implication of chemoprevention of lung cancer. Mol Pharmacol., 68, 635-43. http://dx.doi.org/10.1124/mol.105.011254

Małaczewska, J., Wójcik, R., Jungi, L., \& Siwicki, A. K. (2010). Effect of Biolex $\beta$-HP on Selected Parameters of Specific and Non-Specific Humoral. and Cellular Immunity in Rats. Bull Vet Ins Pulawi., 54, 75-80

Millodot. (2009). Dictionary of Optometry and Visual Science (7th ed.). Butterworth-Heinemann.

Munazir, Z. (2001). Respon Imun Terhadap Infeksi Bakteri. Sari Pediatri, 2(4), 193-197.

Ogier de Baulny, M., Quentel, C., Fournier, V., Lamour, F., \& Le Gouvello, R. (1996). Effect of long-term oral administration of $\beta$-glucan as an immunostimulant or an adjuvant on some non-specific parameters of the immune response of turbot Scophthalmus maximus. Diseases of Aquatic Organisms, 26(2), 139-147. http://dx.doi.org/10.3354/dao026139

Ortuno, J., Cuesta, A., Rodriguez, A., Esteban, M. A., \& Meseguer, J. (2002). Oral administration of yeast, Saccharomyces cerevisiae, enchances the cellular innate immune respon of glithead seabream ( Sparus aurata L). Veterinary Immunology and Immunopathology, 85, 41-50. http://dx.doi.org/10.1016/s0165-2427 (01)00406-8

Pearse, G. (2006). Normal Structure, Function and Histology of the Thymus. Toxicologic Pathology, 34(5), 504-514. http://dx.doi.org/10.1080/01926230600865549

Piao, Y., Liu, Y., \& Xie, X. (2013). Change Trends of Organ Weight Background Data In Sprague Dawley Rats at Different Ages. J Toxicol Pathol., 26(1), 29-34. http://dx.doi.org/10.1293/tox.26.29

Prasenjit, B. H., Hullanti, K. K., \& Kumar Vijay, M. L. (2011). Antithelmintic and antioxidant activity of alcoholic extracts of diffrent parts of Coleus amboinicus Lour.

Preeja, G., Pillai, S., Mishra, G., \& Annapura, M. (2011). Evaluation of the acute and sub acute toxicity of the methanolic leaf extract of Plectranthus amboinicus (Lour) Spreng in balb c mice. Euro. J. Exp. Bio., 1(3), 236-245

Shiney, R. B., Ganesh, P., \& Khumar, R. S. (2012). Phytochemical Screening of Coleus aromaticus and Leucas aspera and Their Antibacterial Activity against Entheric Phatogens. International Journal of Pharmaceutical and Biological Archives, 3(1), 162-166.

Tizard, I. R. (2004). Veterinary Immunology an Introduction. Edisi ke-7. USA: Saunders.

Tong, X, Van Dross, R. T., Abu-Yousif, A., Morrison, A. R., Pelling, J. C. (2007). Apigenin prevents UVB-induced cyclooxygenase 2 expression: Coupled mRNA stabilization and translational inhibition. Mol Cell Biol., 27, 283-96. http://dx.doi.org/10.1128/mcb.01282-06

Uma, M., Jothinayaki, S., Kumaravel, S., \& Kalaiselvi, P. (2011). Determination of bioactive components of Plectranthus amboinicus Lour by GC-MS analysis. New York Science Journal, 4, 66-69. Retrieved from http://www.Sciencepub.net/newyork

Wang, W., Heideman, L., Chung, C. S., Pelling, J. C., Koehler, K. J., \& Birt, D. F. (2000). Cell-cycle arrest at $\mathrm{G} 2 / \mathrm{M}$ and growth inhibition by apigenin in human colon carcinoma cell lines. Mol Carcinog, 28, 102-10. http://dx.doi.org/10.1002/1098-2744

\section{Copyrights}

Copyright for this article is retained by the author(s), with first publication rights granted to the journal.

This is an open-access article distributed under the terms and conditions of the Creative Commons Attribution license (http://creativecommons.org/licenses/by/3.0/). 